\title{
KURUMSAL İMAJ OLUŞTURMADA SPOR SPONSORLUĞUNUN ROLÜ
}

\author{
İsmail KOCABAŞ*
}

\begin{abstract}
ÖZET
Günümüzün rekabet ortamında, markaların hedeflerine ulaşmasında en önemli rolü kurumsal imaj ve itibar oynamaktadır. Olumlu bir kurumsal imaj oluşturmada yaygın olarak kullanılan yöntemlerden birisi de sponsorluk faaliyetleridir. Spor sektörünün her geçen gün daha fazla gelişmesi ve kitleleri doğrudan veya dolaylı olarak kapsamına alması sporun çekiciliğini arttırmaktadır. Sponsorluk, hem sponsor hem de sponsorlu etkinlik için karşılıklı marka ve iş değeri ortaya koyan ilişkisel bir pazarlama aracıdır. Özellikle medyada sürekli yer alması ve büyük kitlelerin ilgisini çekmesi nedeniyle spor faaliyetlerini kapsayan spor sponsorluğu, ürünlerini hedef kitlelere tanıtmayı amaçlayan markalar için önemli firsatlar ortaya koymaktadır. Bu nedenle de markalar, ürünlerini ve hizmetlerini kısa zamanda daha geniş kitlelere ulaştırmak amaciyla spor sponsorluğunu tercih etmektedir. Bu bağlamda spor sponsorluğu olumlu bir imajla birlikte sadık bir tüketici tabanı oluşturmak için oldukça başarılı bir iletişim kanalıdır. Çalışma, kuruluş ve markaların gerek iç gerekse de dış hedef kitlesine yönelik olumlu bir kurumsal imaj oluşturmada spor sponsorluğunu nasıl kullandıklarını ortaya koymayı amaçlamaktadır. Bu bağlamda, literatür taraması sonucunda kurumsal bir imaj oluşturma amacıyla bazı spor dallarının taşıdığı imaj değerleri ortaya konularak spor sponsorluğu faaliyetlerinde önem arz eden hususlar uluslararası bir havayolu markası üzerinden değerlendirilmiştir. $\mathrm{Bu}$ açıdan çalışma, halkla ilişkiler uygulamalarından birisi olan spor sporluğunun, kurumsal imaj oluşturmadaki rolüne değinerek alanın kuramsal gelişimine katkı sunmayı hedeflemektedir.
\end{abstract}

Anahtar Kelimeler: İmaj, Kurumsal İmaj, İmaj Değerleri, Sponsorluk, Spor Sponsorluğu

JEL Sınıflandırma Kodları: H83, L83, M31, O43, Z33.

\section{THE ROLE OF SPORTS SPONSORSHIP IN BUILDING CORPORATE IMAGE} \begin{abstract}
In today's competitive environment, corporate image and reputation play the most important role in achieving brands' goals. One of the commonly used methods of creating a positive corporate image is sponsorship activities. More and more development of the sports sector every day and its direct or indirect coverage of the masses increase the attractiveness of the sport. Sponsorship is a relational marketing tool that creates mutual brand and business value for both sponsored and sponsored events. In particular, due to the constant media coverage and the interest of large audiences, sports sponsorship covering sports activities opens up important opportunities for brands that aim to promote their products to target audiences. For this reason, brands prefer sports sponsorship in order to bring their products and services to a wider audience in a short time. In this context, sports sponsorship is a very successful communication channel to create a loyal consumer base along with a positive image. The study aims to demonstrate how institutions/brands use sports sponsorship to create a positive corporate image for both their internal and external target audience. In this context, as a result of the
\end{abstract}

* (D) İstanbul Rumeli Üniversitesi, Sanat, Tasarım ve Mimarlık Fakültesi, Radyo Televizyon ve Sinema Bölümü, Dr.Öğr.Üyesi, kcbs.ismail@gmail.com 


\section{TÜRKIYE MESLEKI VE SOSYAL BILIMLER DERGISI}

Türkiye Mesleki ve Sosyal Bilimler Dergisi, Aralık 2021, Yıl: 3, Sayı: 7, 16-34. Journal of Vocational and Social Sciences of Turkey, Dec 2021, Year: 3, No: 7, 16-34.

literature review, the image values of some sports branches were revealed in order to create a corporate image and the issues that are important in sports sponsorship activities were evaluated through an international airline brand. From this point of view, the study aims to contribute to the theoretical development of the field by addressing the role of sport sponsorship which is one of the practices of public relations, in creating a corporate image.

Keywords:, Image, Corporate Image, Image Values, Sponsorship, Sport Sponsorship

JEL Classification Codes: H83, L83, M31, O43, Z33.

\section{GİRIŞ}

İnsan hayatının psikolojik ve bedensel sağlığı açısından önemli unsurlar arasında yer alan spor, bireylerin sosyalleşmesine de katkı sunmaktadır. Rolünün bu denli yüksek olduğu insan hayatı içerisinde, sporun öneminin de giderek artması söz konusudur. Bu ise markalar ve kuruluşların gerek spora gerekse de spor sponsorluğuna yönelik faaliyetlerini arttırmaktadır (Baş, 2008:112). Spor sektörünün sürekli olarak gelişmesi ve kitleleri doğrudan ya da dolaylı bir şekilde kapsamına dahil etmesi, sporu bir cazibe merkezi haline getirmiştir. Bunun yanı sıra, yeni spor dallarının ortaya çıkması, sporun insan sağlığına ilişkin olumlu ve önemli etkileri, iletişim teknolojilerinin gelişimiyle birlikte televizyon ve gazete haberleri, sporu bir endüstriye dönüştürmüştür (Tekin ve Eroğlu Eskicioğlu, 2015:115). Günümüzün rekabet ortamında, kuruluşların hedeflerine ulaşmasında en önemli rolü kurumsal imaj ve itibar oynamaktadır. Olumlu bir kurumsal imaj oluşturmada yaygın olarak kullanılan yöntemlerden birisi de sponsorluk faaliyetleridir (Temel ve Sirın, 2017:241). Sponsorluk, hem sponsor hem de sponsorlu etkinlik için karşıllklı marka ve iş değeri ortaya koyan ilişkisel bir pazarlama aracıdır (Collet ve Fenton, 2011:2). Diğer taraftan sponsorluk, bir marka, bir ürün, bir hizmet ve potansiyel veya mevcut tüketici ve müşteriler arasında bir ilişki kurmaktadır (Ferrand vd., 2007:18). Özellikle medyada sürekli yer alması ve büyük kitlelerin ilgisini çekmesi nedeniyle spor faaliyetlerini kapsayan spor sponsorluğu, devasa kitlelere hitap ettiği için ürünlerini hedef kitlelere tanıtmayı amaçlayan kuruluşlar ve markalar için önemli firsatlar ortaya koymaktadır. $\mathrm{Bu}$ nedenle de ürünlerini ve hizmetlerini kısa zamanda daha geniş kitlelere ulaştırma gayreti içerisinde olan kuruluşlar ve markalar tarafindan tercih edilmektedir (Temel ve Sırın, 2017:241). Spor sponsorluğu, dilsel ve kültürel engellerin üstesinden gelme yeteneğine sahiptir ve bu da onu küresel pazarlama için cazip bir seçenek haline getirmektedir. Geleneksel medya aracıllğıyla kitle iletişiminin yerini çok daha güvenilir bir iletişim biçimi almaktadır. Bu bağlamda sponsorluğun özellikle spor alanı üzerinden olumlu bir imaj oluşumuyla birlikte sadık bir tüketici tabanı oluşturmada oldukça başarılı bir iletişim kanalı olduğu kanıtlanmıştır (Melovic vd., 2019:2).

Bu çalışma literatür tarama modelinde olup birinci bölümde, imaj kavramı, imaj türleri ve kurumsal imaj; ikinci bölümde, olumlu bir kurumsal imaj oluşturmaya yönelik temel süreç; üçüncü bölümde sponsorluk olgusu, sponsorluk alanları, sponsorluk ve spor sponsorluğunun gerçekleştirilme amaçları hakkında bilgilere yer verilmektedir. Çalışmanın dördüncü bölümünde kurumsal imaj oluşturma çabası ile spor sponsorluğu arasındaki ilişkiye değinilmektedir. Son bölümde ise, Emirates Havayolları ulaşım markasının üstlendiği spor sponsorluğu faaliyetlerinin kurumsal imaj oluşturmaya yönelik nasıl bir rol oynadığına ilişkin değerlendirmeye yer verilmektedir.

\section{IMMJ KAVRAMI, TÜRLERİ VE KURUMSAL IMAJ}

En genel anlamda bir kişi, kurum ya da duruma yönelik duygu, düşünce ve görüşlerin toplamına imaj denilmektedir. Günümüzde diğer rakiplere göre farkın ortaya konulacağı bir iletişim stratejisine duyulan gereksinim kadar gerek birey gerekse de kuruluş/marka hakkında bilgi verme gerekliliği, imaj kavramını çağımızın olmazsa olmazı haline getirmektedir (Balta Peltekoğlu, 2014:571). 
Türkiye Mesleki ve Sosyal Bilimler Dergisi, Aralık 2021, Yıl: 3, Sayı: 7, 16-34. Journal of Vocational and Social Sciences of Turkey, Dec 2021, Year: 3, No: 7, 16-34.

Farklı araştırmacılar çalışmalarında farklı sayıda imaj türlerine yer vermişlerdir. Tengilimlioğlu ve Öztürk (2004:223-224) çalışmasında imaj türlerinden yedisine, Özer (2009:185-186) on ikisine, Bakan (2005:16-35) ise on dört türüne yer vermiştir. Bu bağlamda literatürde yer edinen belli başlı imaj çeşitleri şunlardır: Kişi imajı, kişinin iletişimin her türlü imkanlarını kullanarak kendisini doğru ve etkileyici bir biçimde ifade etmesidir (Özer, 2013:30). Ayna imajı, üst yönetimden alt kademeye kadar kuruluş bünyesindeki personellerin kendi kuruluşuna ilişkin sahip olduğu algıların toplamıdır (Özer, 2009:185; Polinkevych ve Kamiński, 2018:38). Üst imaj olarak, bir kuruluşun gerçekleştirdiği tüm uygulamaları kapsayan ve kuruluş üzerinde etkisi hissedilen genel imaja şemsiye imaj denilmektedir (Balta Peltekoğlu, 2014:575). Genel itibariyle lüks tüketime yönelik üretim yapan bir markanın imajının farklı bir ürün kategorisine transfer edilmesi, transfer imaj (Bayçu, 2012:59), diğer bireylerin zihninde yer alan görüş ve fikirler yabancı imaj (Balta Peltekoğlu, 2014:575), hedef kitle nezdinde iyi, kaliteli, güçlü gibi bir alg1 ve profile sahip markaların, çevreye yansıyan ve hedef kitlelerde sempati uyandıran imaj türü ise, pozitif imaj olarak ifade edilmektedir (Tengilimlioğlu ve Öztürk, 2004:233). Markaları//kuruluşların saldırgan ve hedef kitlede iyi niyet uyandırmayan davranışları neticesinde ortaya çıkan imaj türüne negatif imaj (Bayçu, 2012:59) denirken, kişi, kuruluş veya markaların hedef kitlede kendisine ilişkin oluşmasını istediği ve hedeflediği imaj türü, istenilen imaj olarak ifade edilmektedir. Kişi, kuruluş veya markaların, hedef kitle nazarında halihazırda yer etmiş imajına, mevcut imaj, kişinin/kurumun/markanın kendisini, kendi iç aynasında görme biçimi ise, öz imaj olarak adlandırılmaktadır (Özer, 2009:182). Genel anlamıla bir ürüne ilişkin alg1 ve izlenimlerin neticesi olarak ortaya çıkan imaj türü ürün imajı olarak tanımlanmaktadır. Rakiplerin fazla olduğu bir pazarda, gerek ürün gerekse de hizmetin diğerlerinden ayrışarak bir adım daha öne çıkmasına olanak sağlamada etkili olan marka imajı, ürünün kurum/kuruluştan bağımsız olarak kendisinin sahip olduğu imaj olarak ifade edilmektedir (Balta Peltekoğlu, 2014:575).

Belirli bir zaman içerisinde kuruluşa ilişkin hedef kitlesinin sahip olduğu alg1, tecrübe, fikir ve deneyimlerin toplamı şeklinde meydana gelen sonuçlar kurum imajı olarak ifade edilebilir (Abd-elSalam vd., 2013:131). Diğer bir deyişle kurumsal imaj, bir kurumun izleyicileri/hedef kitleleri tarafından zihinlerde yer eden resmidir (Gray ve Balmer, 1998, s. 696; Upamannyu vd., 2015:29). Başka bir ifadeyle de, bir kurumun isim veya logosunun görülmesi ya da duyulması neticesinde akla gelenler, kurumsal imajı ifade etmektedir. (Gray ve Balmer, 1998:696).

Kurumsal görünüm/tasarım, kurumsal iletişim ve kurumsal davranışın toplamı neticesinde ortaya çıkan kurumsal imaj, hem iç hem de dış hedef kitle nezdinde güven oluşturmanın yanı sıra bunu sürdürmek ve verimliliği arttırmakla birlikte uzun süreçte itibara katkı sağlamak gibi önemli bir fonksiyonu gerçekleştirmektedir. Kurumsal imaj oluşturma faaliyetleri, kuruluşun görsel göstergeleri olarak kimliğini yansıtan renk, yazı karakteri, logo ve kuruluş adından basılı ambalaj, materyal, sergi, stant ilan ve satış geliştirme yöntemlerinin yanı sıra ortak kurumsal görünümün oluşturulmasına ve yansıtılmasına kadar çok geniş bir yelpazede imajın tüm bileşenlerinin koordinasyonunu içermelidir. Ayrıca kurum iç ve dış iletişimde halkla ilişkiler, reklam, sponsorluk, sosyal sorumluluk faaliyetlerini de içeren, kurumsal iletişim kapsamında verilen mesajlarda görsel kimlikle uyumlu bir şekilde tasarlanmalıdır. Aynı şekilde çalışanların müşteriye karşı davranışlarını, birbirleriyle olan ilişkilerini ve kuruluşla bütünleşmelerini sağlama çabalarını kapsayan kurumsal davranış ise, imajın diğer bileşenleriyle örtüşecek şekilde oluşturulup yönetilmelidir (Balta Peltekoğlu, 2014:572).

\section{KURUMSAL IMAJ OLUŞTURMA SÜRECI}

En genel çerçevede, kurumun/kuruluşun dışa yansıyan görüntüsü olarak ifade edilen kurumsal imajın, güçlü bir şekilde oluşturulmasına ilişkin gerekli dört önemli unsur vardır ve bunların toplamı bir süreci ifade etmektedir. Bunlar (Canöz N. , 2015:32-35): Alt yapı oluşturmak, iç imajı oluşturmak, dış imajı oluşturmak ve soyut imaj oluşturmaktır. 


\section{TÜRKIYE MESLEKI VE SOSYAL BILIMLER DERGISI}

Türkiye Mesleki ve Sosyal Bilimler Dergisi, Aralık 2021, Yıl: 3, Sayı: 7, 16-34.

Journal of Vocational and Social Sciences of Turkey, Dec 2021, Year: 3, No: 7, 16-34.

\subsection{Altyapı Oluşturmak}

Çalışanlar kurumun/kuruluşun vizyonu hakkında bilgi sahibi olduklarında bu hedeflere ulaşmak için motive olmaktadır. Vizyon, çalışanın kuruluşa bağlılı̆̆ını arttırmaktadır. Bununla birlikte çalışanın kuruluşu sahiplenmesine, geleceğe umutlu bakmasına imkan sağlayarak kurumun diş hedef kitlelerine olumlu bir imaj olarak yansımasına yardımcıdır. Etkili bir vizyon geliştirme yoksunluğu, yönetim anlayışı, işletmenin kültürü, insan kaynakları ile bütüncül yaklaşımla bir takım değişim ortaya koyamama ve sağlam bir alt yapı oluşturma yoksunluğunda yapılacak imaj çalışmaları, istenilen sonucu veremeyeceği gibi kurumun gerçek imajını da yansıtamayacağından kısa vadeli olacaktır (Güzelcik, 1999:181-182).

\section{2. İç İmaj Oluşturmak}

Kurum/kuruluş bünyesinde çalı̧̧an personel, bir firmanın kurumsal kimliğini iletirken göz önünde bulundurması gereken iç seçim bölgesini temsil etmektedir. Çalışanların gözünde olumlu bir imajın, yüksek moral ve üretkenliğin başlıca nedensel faktörü olabileceğine inanılmaktadır (Gray ve Balmer, 1998:698). Kurumların, kendi bünyesinde yer alan personellerin nazarında pozitif bir imaj değerine sahip olmas1, personelin aidiyet duygusuyla birlikte motivasyonu üzerinde de önemli bir rol oynayabilmektedir. Bu durum ise, verimliliği arttırmanın yanı sıra, maliyetleri düşürerek yöneticiçalışan ilişkisinde çatışma riskini de en aza indirebilmektedir (Canöz N. , 2015:34). Bu uygulama genellikle Japon üreticilerin başarısının temel bir nedeni olarak gösterilmektedir. Ayrıca, firmanın dış paydaşlara temsil edilmesinde çok önemli bir rol oynadıkları için çalışanlarla olumlu bir imajın bileşik bir etkisi olduğu da unutulmamalıdır (Gray ve Balmer, 1998:698).

\subsection{Soyut İmaj Oluşturmak}

İlk hedefin müşteri tatmini ile müşteri sadakatinin elde edilmesi düşüncesinin olduğu soyut imaj, kuruluşun ne kadar kar elde ettiğinden ziyade gerek birey gerekse de topluma yönelik pozitif açıdan ne düzeyde katk1 sunabildiğiyle oluşturulabilmektedir (Çetin ve Tekiner, 2015:427). K1sacası gerek kurumun hedef kitlesi gerekse de içerisinde bulunduğu toplumun sosyal istek ve beklentilerine karşıllk verebildiği ölçüde zihinlerde bir imaj oluşumu sağlanabilecektir. Bu nedenle de toplumsal olay ve ihtiyaçlara karşı duyarlı olan kuruluşların diğerlerine nazaran daha olumlu bir imaj oluşturma noktasında bir adım daha önde oldukları söylenebilir.

\subsection{Dış İmaj Oluşturmak}

Kurumsal imaj oluşturmadaki önemli unsurlardan birisi de dış imaj oluşturmaktır. Bu kapsamda dış hedef kitlelerden olan aracıların ve tedarikçilerin kuruma yönelik algıladıkları imaj ortak kavramlardan oluşmaktadır. Dolayısıyla işin itibarı, etik iş uygulamalarına uygunluk, güvenilirlik, ortaklara bağlılık, bilgi açıklığı, satış göstergeleri, şeffaflık, pazar payı, fiyatlandırma politikası esnekliği, ürün ve hizmet çeşitliliği gibi parametreler kuruluşların dış imajını oluşturmaktadır (Polinkevych ve Kamiński, 2018:38). Kurumların/kuruluşların dış imaj oluşturmada dikkat etmesi gereken önemli şu beş temel unsur bulunmaktadır; kalite unsuru, somut imaj unsuru, reklam unsuru, medya ile ilişkiler unsuru ve sponsorluk unsuru (Güzelcik, 1999:182). Çalışmanın kapsamı bakımından burada da sponsorluk unsuruna geniş şekilde yer verilecektir.

\section{SPONSORLUK}

Sponsorluk, ticari kazanç hedeflerine ulaşmak için iletişim uygulamalarında kullanılabilecek bir dizi hak karşılığında, bir birey ya da kuruluş (sponsor) tarafından bir birey ya da kuruluşa (hak sahibi) fon, mal ve/veya hizmet kaynaklarının sağlanması neticesinde ortaya çıkan karşılıklı fayda sağlayan bir anlaşmadır (Masterman, 2007:30; Gross, 2015:34). Sponsorluğu üstlenenler sponsor olarak ifade edilmekle birlikte belirli bir ölçüde resmi olarak sorumlu olan yönetim kişisidir. Bu kapsamda sponsor, kaynakları sağlar, barikatları (hedeflere erişimi engelleyici iletişimsel gürültü) kaldırır ve üstlendiği kişi/organizasyon/takım vb. başarısı için yönetim "şampiyonu" olarak hareket etmektedir. 


\section{TÜRKIYE MESLEKI VE SOSYAL BILIMLER DERGISI}

Türkiye Mesleki ve Sosyal Bilimler Dergisi, Aralık 2021, Yıl: 3, Sayı: 7, 16-34. Journal of Vocational and Social Sciences of Turkey, Dec 2021, Year: 3, No: 7, 16-34.

Sponsor ayrıca belirli çerçevede kişi/takım/organizasyon hakkında ne zaman ve ne şekilde olacağına ilişkin karaları da belirlemektedir (Pope S. , 1998:7).

Sponsorluk ilk dönemler için, markaların iletişim stratejisine entegre potansiyeli olan bir iletişim tekniği olarak tasarlanmıştır. Daha sonrasında ise markalar, sponsorluk stratejileri ile pazarlama karmasının diğer değişkenleri arasındaki sinerjiyi, mümkün olan en iyi yatırım getirisini sağlamak için kullanmışlardır (Ferrand vd., 2007:11). Günümüzde ise, sponsorluk öncelikle marka iletişimini ve ilişki yönetimini desteklemek için kullanılan bir pazarlama faaliyeti olarak kabul edilmektedir. Pazarlama fonksiyonu içinde giderek daha fazla yer almaktadır ve sofistike sponsorlar söz konusu olduğunda, diğer pazarlama ve iletişim yöntemlerinin yanı sıra entegre bir pazarlama iletişimi çerçevesi altında faaliyet göstermektedir (Meenaghan, 2005:244).

\subsection{Sponsorluk Türleri ve Sponsorluğun Genel Amaçları}

Kuruluşlar kurumsal ihtiyaç ve hedefleri doğrultusunda spordan sanata, doğadan sosyal alanlara kadar çeşitli sponsorluk faaliyetleri gerçekleştirmektedirler. Literatürde farklı kaynaklarda farklı şekilde sponsorluk yapılan alan sınıflandırmaları bulunmaktadır. Gross'un (2015:36) çalışmasında, markaların üstlendiği sponsorluk dallarında bakıldığında, spor sponsorluğu, kültür-sanat sponsorluğu sosyal sponsorluk, bilim sponsorluğu ve çevre sponsorluklarının ön planda olduğu görülmektedir. Oliver (2004:190), çalışmasında spor sponsorluğu, müzik ve sanat sponsorluğu ile diğer eğlence aktivitelerine yönelik sponsorluklar olarak bir ayrıma giderken, Okay (2012:82) ise, yüksek çehreli sanat sponsorluğu, kitle sanatları, sosyal sponsorluk ve çevre sponsorluğu gibi bir sinıflandırmaya yer vermiştir.

Sponsorluğun gerçekleştirilmesi kapsamındaki genel amaçlarına bakıldığında, marka bilinirliğini arttırmak, marka imajını oluşturmak, değiştirmek ve güçlendirmek, müşteri ilişkilerini geliştirmek, ürün faydalarını göstermek, çalışan sadakatini geliştirmek, satışları teşvik etmek olduğu söylenebilir (Gross, 2015:41-46; Cornwell, 2020: 44). Özellikle, sponsorluk, bir markanın güvenilirliğini ve farkındalığını artırmak, imaj transferlerini geliştirmek ve iş-iş ilişkileri geliştirmek için bir dağıtım ağını veya satış gücünü teşvik etmek (Ferrand vd., 2007:20), markayı yeniden konumlandırmak, diğer sponsorları dışarıda bırakarak rekabet avantajını korumak ve sosyal fedakarlık göstermek amacıyla kullanılmaktadır (Masterman, 2007:34).

Tablo 1. Sponsorluğun Hedef Kitlelere Göre Amaç ve Etkileri

\begin{tabular}{|l|l|l|}
\hline \multicolumn{1}{|c|}{ Hedef Kitle } & \multicolumn{1}{|c|}{ Amaç } & \multicolumn{1}{c|}{ Etkiler } \\
\hline Genel halk & $\begin{array}{l}\text { Kurumsal vatandaşlık } \\
\text { Kurumsal sosyal sorumluluk }\end{array}$ & $\begin{array}{l}\text { Olumlu kurumsal imajı arttırmak } \\
\text { İyi niyet oluşturma }\end{array}$ \\
\hline İç personel & $\begin{array}{l}\text { Kurumsal kültür } \\
\text { Kurumsal imaj }\end{array}$ & $\begin{array}{l}\text { Personel özsaygısını arttırmak } \\
\text { İmaj inşa etmek }\end{array}$ \\
\hline Politikacılar / Düzenleyiciler & $\begin{array}{l}\text { Kurumsal misafirperverlik } \\
\text { İyi niyet oluşturma }\end{array}$ & Eğlence sağlama, ilişki kurma, lobicilik \\
\hline Medya & Kurumsal misafirperverlik & Pozitif kurum algısı oluşturma \\
\hline Ortaklar & Görünürlük & Güvence, kredibilite \\
\hline Tedarikçiler (Materyal, Finans) & İlişki yönetimi & I̧s-ekonomi ilişkilerinin geliştirilmesi \\
\hline Ticari alıcı (Bayi/Toptancı/ Perakendeci) & İlişki yönetimi & İş-ekonomi ilişkilerinin geliştirilmesi \\
\hline Hedef pazar & $\begin{array}{l}\text { Markanın tanınırlı̆̆ı,bilinmesi } \\
\text { Marka/sponsor ortaklığı }\end{array}$ & $\begin{array}{l}\text { Farkındalık inşa etme } \\
\text { Marka değerlerini sürdürme } \\
\text { Tutum-davranış değişikliği ortaya koyma }\end{array}$ \\
\hline $\begin{array}{l}\text { Kurum içi aynı göreve/unvana sahip } \\
\text { olanlar }\end{array}$ & $\begin{array}{l}\text { Başkan'ın seçimi } \\
\text { Kişisel gelişim }\end{array}$ & $\begin{array}{l}\text { Konumunu güçlendirme } \\
\text { Kendini gerçekleştirme }\end{array}$ \\
\hline
\end{tabular}

Kaynak: (Meenaghan, 2005:247)

Sponsorluk Meenaghan'ın ortaya koyduğu çalışmada olduğu gibi, farklı hedef kitlelere göre farklı amaçlarla gerçekleştirilmektedir. Markalar tarafindan gerçekleştirilen sponsorlukların farklı hedef kitleler için farklı çıktıları olmaktadır. Bu çerçevede müşteri dışı paydaşlar söz konusu olduğunda, marka imajı ürün veya hizmet imajlarına üstün gelebilmektedir. Örneğin, tedarikçiler veya hissedarlar 
Türkiye Mesleki ve Sosyal Bilimler Dergisi, Aralık 2021, Yıl: 3, Sayı: 7, 16-34. Journal of Vocational and Social Sciences of Turkey, Dec 2021, Year: 3, No: 7, 16-34.

için kurumsal imaj bir bilgi işlevine hizmet edebilmektedir. Bu durum ise gelecekteki işbirliği ve yatırım faaliyetlerine ilişskin temel dayanak alma amacıyla yoğunlaştırılmış bir izlenim ortaya koyabilmektedir. Ancak potansiyel çalışanlar için belirli bir dereceye kadar değer ifade edici olarak, gelecekteki görev süresine yansımalarında rol oynayabilmektedir (Gross, 2015:84).

\subsection{Spor Sponsorluğunun Amaçları}

Spor sponsorluğu gerçekleştirme, beklenen getiri şekli, yani sponsorların izlediği hedefler, marka bilincini arttırmaktan ekonomik hedeflere ulaşmaya ve genel kurumsal hedeflere ulaşmaya kadar farklı amaçları elde etme gayesiyle gerçekleştirilmektedir (Gross, 2015:33). Bunların en önemlilerinden birisi, marka ya da kurum imajına olumlu açıdan katkı sunma amacıdır. Ancak bu noktada marka imajının olumlu olarak etkilenmesini sağlamak için sponsor olunan kişi/takım ya da etkinlik imajının olumlu olarak algılanmas1 gerekmektedir (Lucas, 2015:119). Bu nedenle bu durumun kuruluşlar tarafından göz ardı edilmemesi önem arz etmektedir. Bunun yanı sıra davranış ve tutumların transfer edilmesi, farkındalık oluşturma, marka sadakati inşa etme, marka farklılaşması, marka iletişimi kurma, kaliteli imajı inşa etme, marka cirosunu arttırma, çalışan motivasyonunu arttırma ve kurumsal karı arttırma gibi amaçlarla spor sponsorluğu gerçekleştirilmektedir (Lucas, 2015:15). Ayrıca kuruluş ya da markaya, ürün algısını, mevcut ve potansiyel sahiplerden önce yerleştirmek için bir reklam firsatı sunma, markanın ürünlerinin teknik gelişimi için ek bir firsat ve platform sağlama, iç ve dış pazarlarında ayırt edici markalaşma ve görüntüleme yoluyla ürünleri ayırt etme gayesiyle de spor sponsorluğu üstlenilebilmektedir (Beck-Burridge ve Walton, 2001:161). Bu çerçevede kuruluşların/markaların, uluslararası sponsorluk anlaşmalarının kavramsal çerçevesine bakıldığında, stratejik uyumluluk açısından vizyon paylaşımı, uyumluluk, tamamlayıcılık, değer katma, pazardan kabul görme, ilişkisel açıdan iletişim, güven, sorumluluk, sonuçları açısından finansal ve finans dış1 memnuniyeti barındırmaktadır (Farrelly ve Quester, 2005:238).

\section{KURUMSAL IMMAJ OLUŞTURMA VE SPOR SPONSORLUĞU İLIŞKİSİ}

Kurum imajı, bir grup insan tarafından kuruma ilişkin akılda tutulan genel, öznel resim olarak tanımlanır. Çok boyutlu bir yapı olarak, kurumla bağlantılı sembolik ve faydacı ilişkilerin tamamını temsil etmektedir (Gross, 2015:71). Kurumsal imaj, ticari kuruluşların ana faaliyet alanlarıyla ilgili olarak geleceğe yönelik stratejik hedeflerine ulaşma araçlarından biri olarak hizmet etmektedir. Olumlu bir imajın oluşması, ticari varlıkların gerçek imajının olumlu olana dönüştürülmesiyle ilgili amaçlı sistematik bir faaliyet gerektirmektedir (Polinkevych ve Kamiński, 2018:38). Küreselleşmeyle beraber rekabetin artması, birbirinden çok farklı olmayan ürünler arasında daha fazla seçici olan bir müşteri kitlesinin oluşmasını da beraberinde getirmiştir. Tüketiciler de karar verme aşamasında deneyim ve duygularıyla bir neticeye varma eğilimi göstermektedirler. Bu açıdan hedef kitlenin duygusal gereksinim ve ihtiyaçlarına yönelik değer ve önemsenme olgusu, kurumsal imaj oluşturma çalışmalarında önemli hale gelmiştir (Özüpek, 2005:163). Farkındalığın ortaya konulmasında, tanıtımın gerçekleştirilmesinde, olumlu bir imaj oluşturulmasında, itibara katkı sağlanmasında ve tüketicilerin satın alma eğilimlerini şekillendirmede önemli bir uygulama olan sponsorluk, kuruluşlar/markalar tarafından sıkça kullanılmaktadır. Diğer taraftan bu noktalar, sponsorluğu bağış ile birlikte yardımdan ayıran özellikler olarak ortaya çıkmaktadır (Canöz ve Doğan, 2015:20).

İmaj, insanların bir olayla ilgili olarak sahip oldukları öznel betimlemeleriyle ilişkilidir. Betimlemede etkinliğin verilen toplumsal etkileri sosyal bir şekilde paylaşılmaktadır. Operasyonel düzeyde, bir etkinliğin imajının o etkinlikle ilişkili tüm çağrışımlarla ilgili olduğu düşünülmektedir. Bir spor etkinliği, belirli bir imajla ilişkili olmasının yanı sıra toplu olarak paylaşılan duyguların üretildiği güçlü bir sosyal eylemdir (Ferrand vd., 2007:14-15).

Çağımızda kurumsallaşmayı, farkındalığı sağlamayı ve rakiplerine nazaran her zaman bir adım daha önde olmayı amaçlayan kuruluşlar, imaj çalışmalarına gereken hassasiyeti göstermek zorunluluğundadırlar. Olumlu bir kurumsal imaj oluşumunda önemli bir etkiye sahip olan sponsorluk, 
Türkiye Mesleki ve Sosyal Bilimler Dergisi, Aralık 2021, Yıl: 3, Sayı: 7, 16-34. Journal of Vocational and Social Sciences of Turkey, Dec 2021, Year: 3, No: 7, 16-34.

üstlenildiği etkinliğin içerdiği anlam çerçevesinde algılanmasına (yardım sever, duyarlı, milli gibi) ve kuruluşun sponsorluklarla anılmasının yanı sıra etkinliğin ya da bireysel çalışmanın olumlu ve başarılı imajından yararlanılarak yeni, olumlu bir imaj oluşturulmasına yardımcı olmaktadır (Canöz ve Doğan, 2015:34). Sponsorluk kelimesi temel anlamda, bir kuruluşun belirli bir ölçüde diğerinin sorumluluğuna destek olması anlamına gelir (Cornwell, 2020:19). Doğru tasarlanmış şekilde yürütülen sponsorluk, marka oluşturma, paydaşları dahil etme ve karlı ticari firsatlar sunma konusunda eşsiz bir güce sahiptir (Collet ve Fenton, 2011:1). Ancak bu noktada sponsorluk faaliyeti çerçevesinde kuruluşların/markaların ve sponsor olunacak etkinliğin ülkelere göre imaj değerlerinin farklılık gösterebileceği hususu dikkate alınmalıdır (Lucas, 2015:144). Diğer taraftan ticari kuruluşların kurumsal imaj oluşturma prosedürü, dış çevre üzerindeki bir etki aracı olarak imajın pozitif olana yaklaştırılması ve böylece şirketin "pazar gücünü” arttırması gerektiği varsayımına dayanmaktadır. Sonuç olarak, ticari kuruluşların kurumsal imajını karakterize eden parametreler olumlu bir imajla uyumlu olmalıdır (Polinkevych ve Kamiński, 2018:38).

Sponsorluğun kurum kimliği üzerindeki etkisi, sponsorluğun imaj1 etkilemesi ve imaj1 oluşturan kurum kimliğinin de bir geri bildirim çemberi içerisinde bundan etkilenmesi şeklinde olmaktadır. Kuruluşların amaçları ve hedefleri doğrultusunda sponsor olacakları spor, sanat-kültür ve sosyal seyahatler gibi alanlara para veya materyal desteği sağlaması olumlu bir imaj oluşturmada yardımcı olabilecektir. Kuruluşlar/markalar, kurum kimliklerinin görsel yönünün, hedef müşteri ve tüketiciler nezdinde yer etmesini sağlamasının yanı sıra olumlu bir imaj oluşturma gayesiyle sponsorluk gibi bir iletişim çalışmasını yürütmektedirler (Okay A. , 2013:165). Bu durumda, marka vizyonuyla sponsorluk vizyonunun uyum sağlaması önemlidir. Sponsorluk vizyonu, gençlerle bağlantı kurmaya ve sponsorluk portföyü boyunca tutarlılık sağlamaya dayanmaktadır. Vizyon, firmanın sponsorluklarının aktivasyonu yoluyla tasarlanan, gençliği geliştirmeye, eğitimi ilerletmeye ve sponsorluk aktivasyonlarının bir kısmında veya hepsinde toplulukları kucaklamaya odaklanan tutarlı bir iş parçacığıdır. (Collet ve Fenton, 2011:38).

Tüketiciler, reklamı ekonomik kar elde etme içerikli bir iletişim şekli olarak gördüğü için reklamları kuruluşun çıkarının olduğu bir şey gibi düşünmektedirler. Fakat spor sponsorluğu faaliyetleri yapan kuruluşların/markaların tüketicilerin gözünde daha iyi niyetli görüldükleri söylenmektedir (Öztürk, 2013:19). Dolayısıyla spor sponsorluğu yapmak ticari kuruluşların farkındalığını arttırdığı bir alan olarak görülmektedir (Yelken ve Ak, 2018:296). Kuruluşlar tarafından spor sponsorluğun tercih edilmesinde sporun göz önünde olması, herkesin katılabilmesi, saatlerce seyredilmesi, sürekli olarak medyada yer alması, sporcuların hayatlarının merak edilmesi gibi farklı nedenler sıralanabilir (Çoşkun, 1999:66). Spor sponsorluğu kapsamındaki imaj terimi, bir varlığa (etkinlik, marka, sporcu vb.) ilişkin algıların toplamına karşılık gelmektedir. Sponsorluğun imaj transferi bağlamında, sponsorun amacı bir spor etkinliğinin imajını kendi markasına, hizmetine veya ürününe uygun hale getirmektir. Bir markanın/kuruluşun imajı satın alma kararlarını etkilemektedir. Sponsorun imajı, kimliği ve sportif varlık imajı arasındaki karşılıklı ilişkilendirmedir (Ferrand vd., 2007:21). Sponsorluğu gerçekleştirme amaçlarından birisi olan farkındalı̆̆ı sağlamak için yapılan spor sponsorluğu sayesinde marka/kuruluş, tüketicilere adını duyurmakta ve neticesinde bir marka/kuruluş imajı oluşturmaktadır (Yaman ve Açıközoğlu, 2016:536).

Spor sponsorluğunun temel hedefleri olumlu imaj oluşturma, tutum, sadakat ve tüketiciler arasında marka bilinirliğinin artmasıdır. Bununla birlikte, belirli hedefler de satın alma niyet ve kararlar üzerindeki etkisini içine alan davranışsal amaçlarla da ilgilidir. Tüketiciler bile marka tanıtımı ile marka bilinirliğini arttırma çabalarının arkasında, sponsorluğun ana nedenleri olarak imaj ve itibarı güçlendirme olduğunu ifade etmekte ve bu da sponsorlara olan bağlllıkları üzerinde olumlu bir etkisinin olduğunu ortaya koymaktadır (Melovic vd., 2019:2). Diğer taraftan bir markanın/kuruluşun ürününü takip etme niyeti ile bir markanın/kuruluşun bir sporcu veya spora sponsor olduğu inancı, markanın/kuruluşun kurumsal imajıyla kendisi arasında önemli bir ilişki barındırmaktadır. Çünkü sponsorluk bilinci ile satın alma niyeti arasındaki doğrudan ilişkiye ek olarak, bir markanın/kuruluşun 


\section{TÜRKIYE MESLEKI VE SOSYAL BILIMLER DERGISI}

Türkiye Mesleki ve Sosyal Bilimler Dergisi, Aralık 2021, Yıl: 3, Sayı: 7, 16-34.

Journal of Vocational and Social Sciences of Turkey, Dec 2021, Year: 3, No: 7, 16-34.

kurumsal imaj1 ile o markanın/kuruluşun ürünlerini satın alma niyeti arasında doğru orantılı bir yönelim bulunmaktadır (Pope ve Voges, 2000:100).

Kurumsal hedeflerine ulaşabilmek ve pazarlama amaçlarını desteklemek niyetiyle lig, etkinlik, organizasyon, sporcu, forma gibi bir spor olgusuna yönelik yatırım yapma, spor sponsorluğu olarak tanımlanmaktadır (Argan ve Katırc1, 2002:381). Sponsorluğun ana kategorileri mekanlar, ekipmanlar; aktiviteler, etkinlikler, programlama; gruplar, bireyler; organizasyonlar, ligler ve derneklerdir. $\mathrm{Bu}$ çeşitli sponsorluk kategorileri bağımsız olabilmesinin yanı sıra bir lig, takım ve bireylerin sponsorları da olabilir (Cornwell, 2020:19). Bireysel tüketici düzeyinde, marka imajının sponsor olunan etkinliğin imajından, marka bilinirliğinden, takım fandomundan ve sahipliğinden etkilendiğini göstermektedir. Ulusal bir yarışın etkinlik imajı ile sponsorun marka imajı arasındaki ilişki üzerinde olumlu bir etkisi bulunmaktadır. Reklam harcamaları, "Formula 1" ile ilgili reklam harcamalarının aksine, sahipliğin marka imajı üzerindeki ilişkisini olumlu yönde etkilemektedir. Sadece motor sporlarına olan ulusal ilgi, F1 izleyici kitlesi ve sponsorluğun kabulü gibi dolaylı olarak etkilenebilir değişkenler marka imaj1 üzerinde olumlu bir etkiye sahiptir. (Lucas, 2015:132-133). Bununla birlikte her sponsorluk etkinliği veya alanları gerek iç gerekse de dış hedef kitleye yönelik transfer edilebilecek spesifik bir imaj değeri taşımaktadır. İmaj transferi, sponsor ve etkinliğe ilişkin çok farklı türde yaygın algı, sponsor ve etkinliğin çağrışımlarına ilişkin hedef kitlenin tutumları tarafından olumlu yönde bir etkiye neden olabilmektedir (Yılmaz, 2007:592). Markalar tarafindan gerçekleştirilen sponsorluk faaliyetlerinin bazı imaj değerleri bulunmaktadır. Örneğin bir kuruluş, sağlıklı, genç, enerjik, hızlı, canlı ve erkeksi bir imaj değeri ya da değerlerinden birisini oluşturma amaciyla spor sponsorluğu yapabilir. Bunun yanı sıra bazı sponsorluk alanları şu imaj değerlerine sahiptir; yüksek çehreli sanat sponsorluğu, sofistik, seçkin, ayrımc1, üst pazar, ciddi ve gösterişçi; kitle sanatları, genç, ulaşılabilir, arkadaş canlısı, revaçta olan, yenilikçi ve ticari; sosyal sponsorluk, takdire şayan, düşünceli, ilgilenen, akıllı ve istismar edici; çevre sponsorluğu, ilgili, düşünceli ve istismar edici (Okay A. , 2012:82).

Tablo 2. Spor Branşlarının İmaj Değerleri

\begin{tabular}{|l|c|c|c|c|c|c|c|c|}
\hline \multirow{2}{*}{ Spor Branşları } & \multicolumn{9}{c|}{ İmaj İceriği } \\
\cline { 2 - 10 } & Estetik & Dayanıkllık & Dinamizm & Modernlik & Prestij & Teknik & Geleneksel & Popülarite \\
\hline Aerobik & + & + & & + & & & & \\
\hline Atletizm & & + & + & & & + & + & + \\
\hline Basketbol & + & + & + & + & & + & & + \\
\hline Bilardo & + & & & + & + & + & + & + \\
\hline Binicilik & + & & & + & + & + & + & + \\
\hline Bisiklet & + & + & + & + & & + & & + \\
\hline Boks & & & + & & & + & + & + \\
\hline Buz Dansı & + & & & + & + & & & + \\
\hline Futbol & & + & + & & & + & + & + \\
\hline Golf & + & & & + & + & + & & + \\
\hline Jimnastik & + & & + & & & + & + & + \\
\hline Kayak & + & & + & + & & + & & + \\
\hline Motor Sporları & & + & + & + & & + & & + \\
\hline Araba Yarıșları & & & + & + & + & + & & + \\
\hline $\begin{array}{l}\text { Motosiklet } \\
\text { Yarışları }\end{array}$ & & + & + & + & & + & & + \\
\hline Ralliler & & + & + & & & + & & + \\
\hline Polo & + & & + & + & + & + & & + \\
\hline Satranç & & & & & & & & + \\
\hline Tenis & + & & + & + & + & + & + & + \\
\hline Voleybol & + & & + & + & & + & & + \\
\hline
\end{tabular}

Kaynak (Brünen'den Akt. Soyer, 2003:67)

Her bir sponsorluk alanı belli bir imaj değerine sahiptir. Ancak markalar/kuruluşlar üstlenecekleri spor sponsorluğu aracılığıyla, içerisinde barındırdığı çok sayıda spor branşının kendilerine özgü taşıdıkları 


\section{TÜRKIYE MESLEKI VE SOSYAL BILIMLER DERGISI}

Türkiye Mesleki ve Sosyal Bilimler Dergisi, Aralık 2021, Yıl: 3, Sayı: 7, 16-34. Journal of Vocational and Social Sciences of Turkey, Dec 2021, Year: 3, No: 7, 16-34.

imaj değerleri ile daha spesifik algıları kendi marka ve kurumlarına transfer edebilme olanağına sahip olmaktadır. Tablo 2'de yer alan çeşitli spor dallarında görüldügü gibi her spor branşının bazı ortak imaj değerleri olsa da farklılaştıkları da görülmektedir. Bu nedenle marka ve kuruluşların kurumsal hedefleri doğrultusunda oluşturmak istedikleri olumlu ve spesifik imaja yönelik kullanabilecekleri çok sayıda spor branşı bulunması, spor sponsorluğunu diğerlerine nazaran daha cazibeli bir konuma getirmektedir.

Medya, bir markanın/kuruluşun kurumsal imajını ve itibarını oluşturmada orta düzeyde de olsa bir rol oynamaktadır. Medya mesajlarına maruz kalma kaynaklı olarak kurumsal itibarın aşağı yönlü riski, genel olarak itibar ve imaj geliştirme için yukarı yönlü potansiyelden daha fazladır (Gray ve Balmer, 1998:700). Bu nedenle, bazen kuruluşların ortaya koydukları faaliyetlerde bu tür bir sorunla karşılaşma riskini en aza indirmek amacıyla da spor sponsorluğunu üstlendikleri söylenebilir. $\mathrm{Bu}$ eğilimin temel nedeni, üstlenilen sponsorluğun medya karmaşasından kaçınabilme olanağı ve bir markanın hedef pazarıyla iletişim kurabileceği ve kendisini rakiplerinden ayırt edebileceği bir ortam sunmasıdır. Markanın veya kuruluşun pazarlama stratejisi çerçevesinde yararlanacağı sponsorluk aracılığıyla sunulan marka oluşturma/imaj oluşturma avantajı, marka konumunun artikülasyonudur (Roy, 2005:156). Ancak bunun yanı sıra, sosyal medyanın gücünü kullanmak sponsorluğun gerçekleştirilme amaçlarının elde edilmesine yardımcı olabilmektedir. Sosyal medya, kurumsal imaj oluşumunda çok verimli bir mecra olma avantajına sahiptir. Çünkü Twitter veya Facebook üzerinden bir kişiliğin veya etkinliğin hayranları gibi daha çok sayıda birey ya da tanımlanmış gruplara kolay erişim sağlanmaktadır. Özellikle bu mecralarda, sporseverler her zaman veri ve haberlere aç bir konumda olup, hedef kitlesine bilgi ve iç görü sağlamada yardımcı olacak sponsorların iyi niyet kazanması büyük olasıdır (Collet ve Fenton, 2011:228).

Görsel 1. Spor Sponsorluğunda Marka/Kurum İmaj1 Oluşturma Süreci

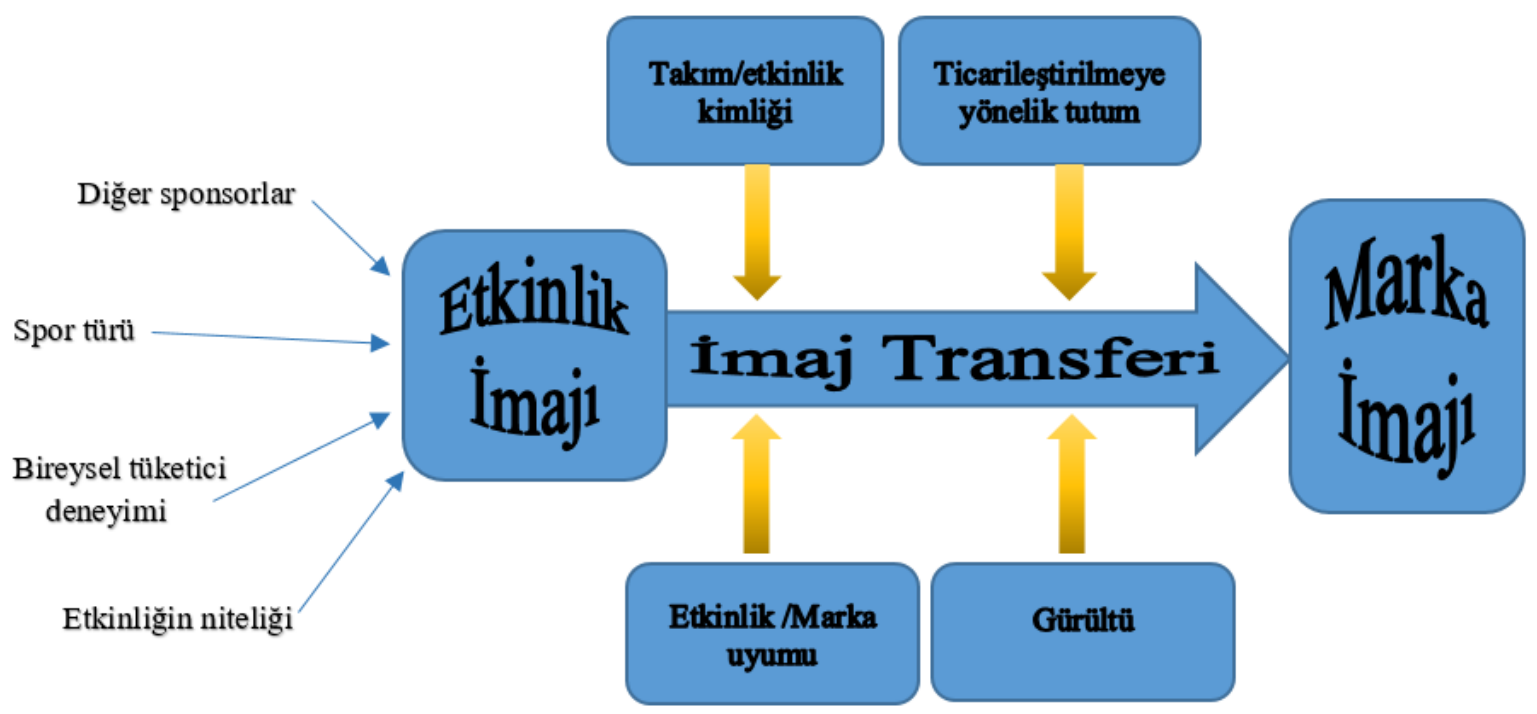

Kaynak (Gwinner, 2005:164)

Birey bir markaya/kuruluşa kayıtsızsa veya ona karşı olumsuz bir tutuma sahipse, markanın/kuruluşun birey tarafından beğenilen bir etkinliğe sponsor olduğu öğrenilirse daha olumlu hislere sahip olunabilir. Yani Görsel 1'de yer aldığı gibi etkinliğin niteliği kurumsal bir imaj oluşturmada daha başlangıçta önemsenmesi gereken bir unsur olarak karşılaşılmaktadır. Avustralya'da yapılan araştırmalar, olumlu bir imaja sahip spor takımlarının, olumsuz bir imaja sahip bir sponsorla eşleştirildikten sonra zarar görebileceğini ortaya koymuştur. Bu açıdan gerek sponsor olan 


\section{TÜRKIYE MESLEKI VE SOSYAL BILIMLER DERGISI}

Türkiye Mesleki ve Sosyal Bilimler Dergisi, Aralık 2021, Yıl: 3, Sayı: 7, 16-34. Journal of Vocational and Social Sciences of Turkey, Dec 2021, Year: 3, No: 7, 16-34.

marka/kuruluş gerekse de sponsor olunan sporcu, takım ve etkinlik yetkilisi bu durumu dikkate alarak bir planlama gerçekleştirmelidir. Aksi takdirde, üstlenilen böyle bir sponsorluk uygulaması olumlu kurumsal bir imaj oluşturmada hedefin sapmasına neden olabilir. Ayrıca, bir ortak tarafindan tutulan herhangi bir anlamın (algıların, imaj değerinin) diğerine aktarılabileceği de söz konusu olabilmektedir (Cornwell, 2020:80). Bu nedenle Görsel 1'de görüldüğü gibi diğer sponsorların hedef kitle zihninde taşıdığı anlamların önemini ön plana çıkarmaktadır. Spor etkinliğinin sponsorluğunu üstlenen bir markaya/kuruluşa yönelik tutumun, bu marka/kuruluş için satın alma niyetleri üzerinde olumlu bir etkisi olduğunu ortaya koymuştur. Dolayısıyla sponsor markaya/kuruluşa ilişkin tutum, sponsor ve etkinlik arasındaki (işlevsel ve imajla ilgili) uyumdan ve markanın/kuruluşun bu etkinliğin sponsoru olarak yer alması için algılanan güvenilirliğinden etkilenmektedir (Masterman, 2007:36; Gross, 2015:78). Özellikle üç faktör sponsor imaj1 üzerinde doğrudan önemli bir etkiye sahiptir: etkinlik imaj1, etkinlik sponsoru uyumu ve sponsorluğa maruz kalma. Olumlu bir etkinlik imajı ve yüksek algılanan uyum, sponsor (marka/kuruluş) imajına fayda sağlamaktayken, daha yüksek düzeyde sponsorluk maruziyeti bu değeri düşürmektedir. Sponsorluğa maruz kalma aynı zamanda etkinliksponsor uyumu ile de etkileşime girmekte ve böylece etkinlik-sponsor uyumu düşükse daha uzun bir sponsorluğa maruz kalma daha az olumlu bir sponsor imajıyla sonuçlanmaktadır. Benzer şekilde, daha uzun sponsorluk maruziyetleri algılanan olayın ticarileştirilmesinin sponsor imajı açısından daha olumsuz etkilere neden olduğunu ortaya koymaktadır. Tüketiciler/Müşteriler genellikle etkinliğin ticarileştirilmesine karşı çıkmamaktadırlar. Çünkü sponsorların, etkinliğin gerçekleştirilmesine olan katkılarını kabul etmektedirler. Sadece yüksek sponsorluğa maruz kalma durumlarında, tüketiciler markaları/kuruluşları olayı aşırı derecede istismar edici olarak görmektedirler (Grohs ve Reisinger, 2014:1023). Bu nedenle tüketiciler/müşteriler sponsorluk etkinliğinin içerisinde daha fazla yer alır ve belirli düzeyde sponsorluk mesajlarına maruz kalırlarsa, bu durumun markanın/kuruluşun imajına daha olumlu katkılar sağlayacağı söylenebilir.

\section{KURUMSAL İMAJ OLUŞTURMADA SPOR SPONSORLUĞUNUN ROLÜNE YÖNELİK EMIRATES HAVA YOLLARI ÖRNEĞİ}

2014 yılında Brand Finance tarafindan dünyanın en değerli havayolu markası seçilmesi, 2016 yılında dünyanın en iyi havayolu şirketi seçilerek üst üste 12. kez en iyi uçak içi "eğlence sistemi" ödülü alması, 2020 yılında The Airline Passenger Experience Association tarafından "yolcuların seçimi" ödülü alması ve 2021 yılında APEX resmi beş yıldızlı uluslararası havayolu üyesi olması nedeniyle Emirates Havayolları üzerinden bir değerlendirme yapılacaktır.

Tablo 3. Emirates Hava Yolları Spor Sponsorlukları

\begin{tabular}{|c|c|c|c|c|}
\hline \multirow{6}{*}{ 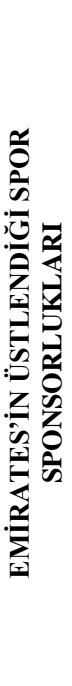 } & \multirow[b]{2}{*}{ Spor Dalları } & \multicolumn{3}{|c|}{ Spor Sponsorluğu Uygulama Alanları } \\
\hline & & Organizsayon/Etkinlik & Takım & Bireysel \\
\hline & Futbol & $\begin{array}{l}\text { Asya Futbol Konfederasyonu } \\
\text { The Emirates FA Cup }\end{array}$ & $\begin{array}{l}\text { Milan } \\
\text { Arsenal } \\
\text { Olympiacos FC } \\
\text { Olympique } \\
\text { Lyonnais } \\
\text { Real Madrid } \\
\text { S. L. Benfica }\end{array}$ & - \\
\hline & Rugby & $\begin{array}{l}\text { Emirates Airline Dubai Rugby Sevens } \\
\text { Cape Town Sevens } \\
\text { BAE Rugby Federasyonu }\end{array}$ & $\begin{array}{l}\text { Emirates Lions } \\
\text { Dubai Hurricanes } \\
\text { Futbol Kulübü }\end{array}$ & $\begin{array}{l}\text { "World Rugby" Hakem } \\
\text { ve maç görevlileri } \\
\text { üniforma sponsoru }\end{array}$ \\
\hline & Tenis & $\begin{array}{l}\text { ABD Açık } \\
\text { ATP Turnuvası } \\
\text { Roland Garros } \\
\text { Dubai Tenis Şampiyonası } \\
\text { Avustralya Açık }\end{array}$ & - & - \\
\hline & Motor Sporları & Formula 1 & - & - \\
\hline
\end{tabular}




\section{TÜRKIYE MESLEKI VE SOSYAL BILIMLER DERGISI}

Türkiye Mesleki ve Sosyal Bilimler Dergisi, Aralık 2021, Yıl: 3, Sayı: 7, 16-34. Journal of Vocational and Social Sciences of Turkey, Dec 2021, Year: 3, No: 7, 16-34.

\begin{tabular}{|c|c|c|c|}
\hline At Yarışları & $\begin{array}{l}\text { Dubai Dünya Kupası Karnavalı } \\
\text { Melbourne Kupası } \\
\text { Dubai Dünya Kupası } \\
\text { Godolphin } \\
\end{array}$ & - & - \\
\hline Golf & $\begin{array}{l}\text { Avrupa Turnuvası } \\
\text { Hong Kong Open } \\
\text { DP Dünya Turnuvası Şampiyonası } \\
\text { WGC-HSBC Champions } \\
\end{array}$ & - & - \\
\hline Kriket & $\begin{array}{l}\text { Uluslararası Kriket Konseyi (International } \\
\text { Cricket Council - ICC) ICC Erkekler Kriket } \\
\text { Dünya Kupası } \\
\text { ICC Kadınlar Kriket Dünya Kupası Erkekler } \\
\text { T20 Dünya Kupası } \\
\text { Kadınlar T20 Dünya Kupası } \\
\text { ICC } 19 \text { Yaş Altı Kriket Dünya Kupası } \\
\text { ICC Erkekler }\end{array}$ & $\begin{array}{l}\text { Collingwood Futbol } \\
\text { Kulübü }\end{array}$ & - \\
\hline Bisiklet Yarışları & - & $\begin{array}{l}\text { UAE Team } \\
\text { Emirates }\end{array}$ & - \\
\hline Yelken & Amerika Kupası Dünya Serisi Portsmouth & $\begin{array}{l}\text { Emirates Team New } \\
\text { Zealand }\end{array}$ & - \\
\hline
\end{tabular}

Tablo 3'e göz atıldığında, havayolu markasının çok farklı spor branşlarında (futbol, rugby, tenis, motor sporları, at yarışları, golf, kriket, bisiklet yarışları ve yelken) farklı spor sponsorluğu alanlarında (organizasyon/etkinlik, takım ve bireysel) faaliyetler gerçekleştirdiği görülmektedir. Ancak markanın spor sponsorluğu üstlendiği alanlara bakıldığında sırasıyla en çok organizasyon/etkinlik $(n=26)$, takım $(n=12)$ ve bireysel $(n=1)$ olarak ön plana çıkmaktadır. Bu noktada, sporcunun başarı seviyesi, yaşam tarzı ve kişisel karakteristik özellikleri gibi birçok farklı unsurdan etkilenebilmesi nedeniyle bireysel sponsorlukların büyük risk olarak görülebilmesi nedeniyle, markalar tercihlerini diğer alanlardan yana kullanmaktadır (Collet ve Fenton, 2011:39).

\subsection{Futbol}

Evrensel bir spor dalı olan futbolda, gerek organizasyonlar/etkinlikler gerekse de futbol takımlarına yönelik sponsorluklar üstlenen Emirates, bu alanda ön plana çıkan markalardan birisi olmuştur. Burada takımların sponsorluğu yapıldığı görülmektedir. Verilen desteği hedef kitlenin görebilmesi, sponsorun fark edilebilmesi için takım oyuncularının formalarının yanı sıra oyun sahasının kenarlarında yer alan reklam panoları ve takım otobüsünün giydirilerek sponsorun ismine yer verilmesi gibi uygulamalar da gerçekleştirilmektedir (Baş, 2008:114).

Görsel 2. Futbol Sponsorluğu ve İmaj Değeri

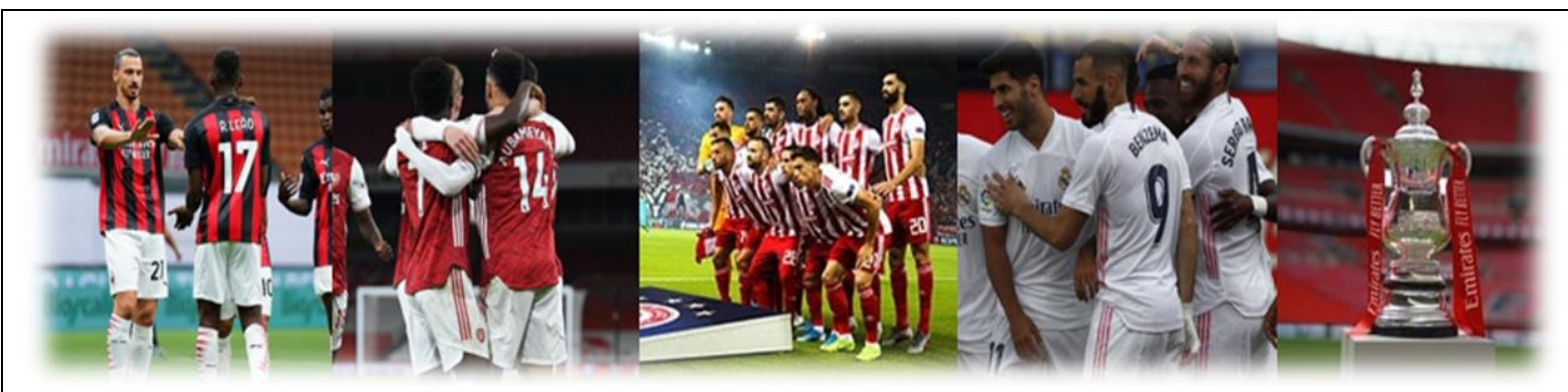

İmaj Değeri: Markanın, hem "Asya Futbol Konfederasyonu" ve "The Emirates FA Cup" organizasyonlarıyla birlikte küresel, uluslararası pazar oyuncusu imajını, hem de İngiltere, İtalya, İspanya, Fransa, Portekiz ve Yunanistan gibi ülkelerdeki hedef kitlelerine yönelik ülke liglerinde yer alan futbol takımlarına sponsor olarak genç, sağlık, dayanıklılık, teknik, geleneksel, dinamizm, popüler olma ve destekçi bir imaj oluşturma gayreti içerisinde olduğu söylenebilir. 


\section{TÜRKIYE MESLEKI VE SOSYAL BILIMLER DERGISI}

Türkiye Mesleki ve Sosyal Bilimler Dergisi, Aralık 2021, Yıl: 3, Sayı: 7, 16-34.

Journal of Vocational and Social Sciences of Turkey, Dec 2021, Year: 3, No: 7, 16-34.

\subsection{Rugby}

Marka, 30 yıldan fazla "Emirates Airline Dubai Rugby Sevens'ın" ana sponsorluğunun yanı sıra, "Cape Town Sevens'ın" sponsorluğunu da üstlenmektedir. İlk defa Fransa'da 2007 yılında "Rugby World Cup" turnuvasının sponsorluğunun üstlenilmesinden bu yana "Yeni Zelanda, İngiltere ve Japonya'da" sırasıyla 2011, 2015 ve 2019 yıllarındaki turnuvalarda sponsor olarak boy göstermiştir. Ayrıca turnuvanın üst düzey hakemlerine yönelik üstlenilen sponsorlukla tüm maçlarda görev alan hakemlerin üzerlerinde markanın "Emirates Fly Better" sloganına maruz kalmaları sağlanmıştır.

Görsel 3. Rugby Sponsorluğu ve İmaj Değeri

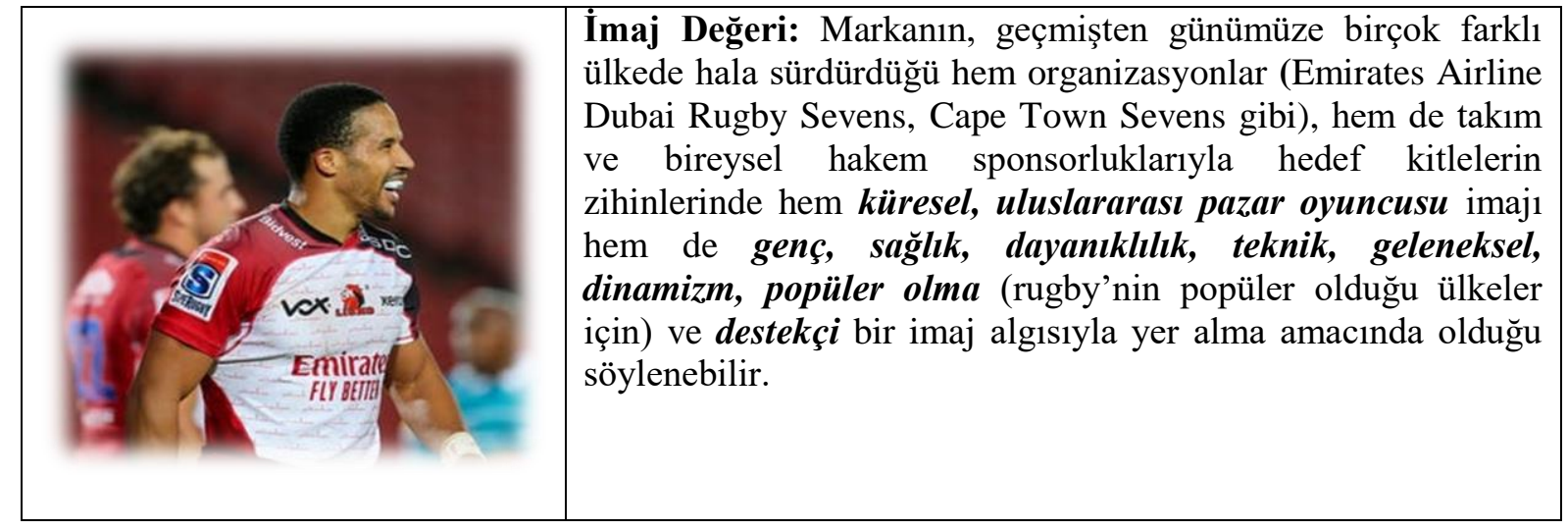

\subsection{Tenis}

Marka, tenis spor dalında dört Grand Slam'in üç tanesi dahil olmak üzere ATP ve WTA gibi elit turnuvalarında sponsor olarak yer almaktadır.

Görsel 4. Tenis Sponsorluğu ve İmaj Değeri

İmaj Değeri: Markanın, tenis sporunun barındırdığı estetik,
dinamizm, modernlik, prestij ve teknik gibi imaj değerlerini
kendi markasına yansıtma amacında olduğu söylenebilir.
Ayrıca, tenis sporunun karakteristiğine bakıldığında,
zamanlamanın ve zaman kullanımın ne kadar önemli olduğunu
ve hatta saniyelerle bir topu karş1lama pozisyonunun galibiyet-
mağlubiyet sonucu üzerinde ne kadar etken olduğu
tartış1mazdır (Koçak vd., 2020:622). Bu aç1dan markanın bir
havayolu şirketi olduğu düşünüldüğünde, dakiklik ve zaman
kazandiran bir marka oldukları imajı ortaya koyma gayreti
içerisinde olduğu söylenebilir.

\subsection{Motor Sporları}

Marka, motor sporları dalında 2013 yılından bu yana F1'in global iş ortağı olarak sponsorluk faaliyetlerini yürütmektedir. 


\section{TÜRKIYE MESLEKI VE SOSYAL BILIMLER DERGISI}

Türkiye Mesleki ve Sosyal Bilimler Dergisi, Aralık 2021, Yıl: 3, Sayı: 7, 16-34. Journal of Vocational and Social Sciences of Turkey, Dec 2021, Year: 3, No: 7, 16-34.

Görsel 5. Motor Sporları Sponsorluğu ve İmaj Değeri

\begin{tabular}{|l|l|}
\hline Imirates FIV BETIE. & $\begin{array}{l}\text { İmaj Değeri: Marka, F1 gibi dünyaca ünlü bir motor sporuna } \\
\text { ilişkin gerçekleştirdiği sponsorluk ile özellikle prestij ve popüler } \\
\text { imaj değerini kendi markasına yansitmanın yanı sıra, spor } \\
\text { içerisindeki güçlü araba modelleri ile onları markaları } \\
\text { üzerinden dayanıklılı, dinamizm, modernlik ve teknik bir } \\
\text { marka imajı oluşturma çabası ortaya koyduğu ifade edilebilir. } \\
\text { Bunun yanı sı, motor sporlarına yönelik desteğiyle rekabete } \\
\text { hazır rekabetçi bir marka olduğu algisını oluşturmaya çalıştığ } \\
\text { söylenebilir. }\end{array}$ \\
\hline
\end{tabular}

Rekabetçi motor sporları, uygun üreticinin mevcut ve potansiyel müşterileri ürünlere dahil etmesi ve yakınlık derecesini arttırması için bir firsattır. Motor sporlarının bir pazarlama aracı olarak etkinliği konusunda çok az şüphe bulunmaktadır. Sağladığı kapsam ve tüketicilere sunduğu erişim derecesiyle birlikte tedarikçinin üretici ile olan ilişkisini, markayı pazarlama amacıyla fon sağlayarak ortaklıklar oluşturmak için kullandığı bir spor dalı olarak ön plana çıkarmaktadır (Beck-Burridge ve Walton, 2001:168).

\subsection{Golf}

Marka, golf spor dalında dünyanın en iyilerinin yer aldığı “Avrupa Turnuvası'nda" Avrupa ve dünya genelinde çeşitli organizasyonlarda yer alarak "Avrupa Turnuvası'nın” 10 yıldan daha fazla resmi havayolu iş ortağı olarak sponsorluk desteği vermektedir.

Görsel 6. Golf Sponsorluğu ve İmaj Değeri

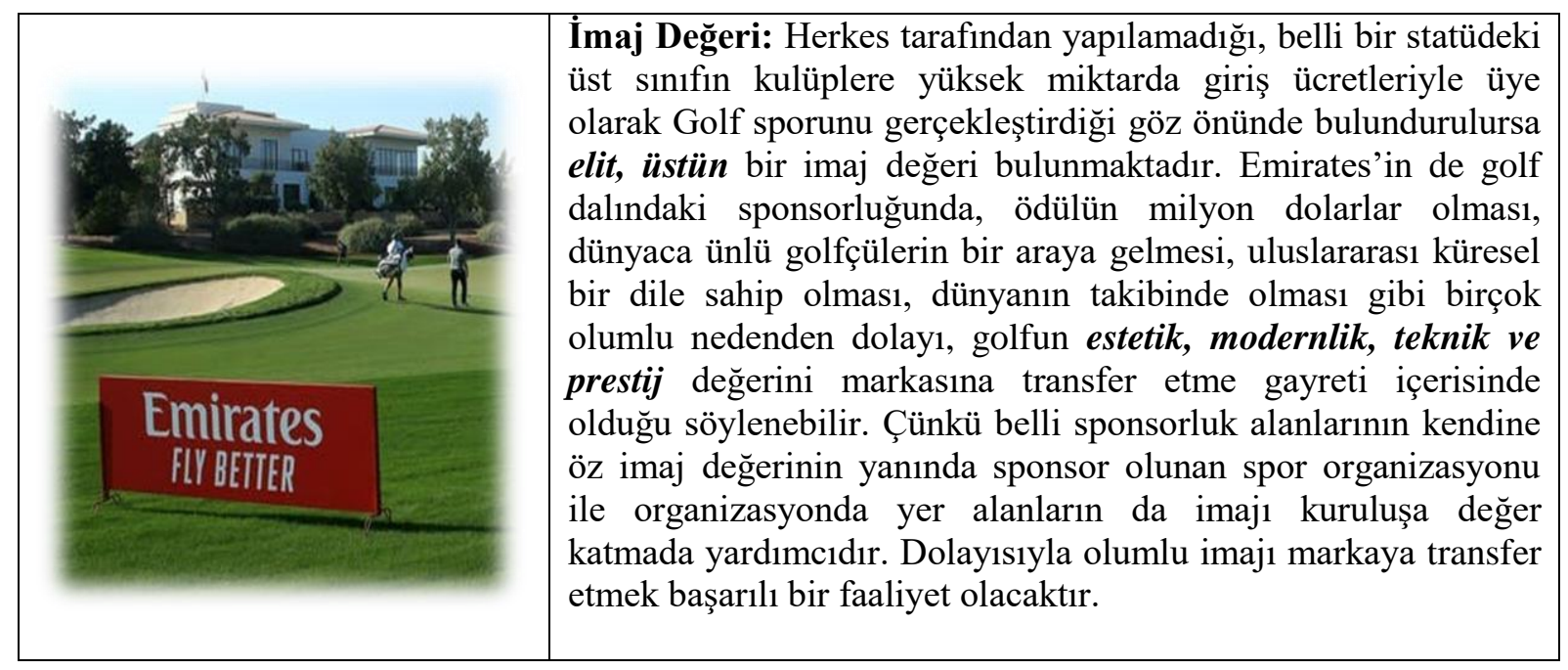

\subsection{At Yarışları}

Marka, at yarışları dalında "Melbourne Kupası, Dubai Dünya Kupası ve Godolphin" gibi farklı organizasyonlarda sponsor olarak yer almaktadır. 


\section{TÜRKIYE MESLEKI VE SOSYAL BILIMLER DERGISI}

Türkiye Mesleki ve Sosyal Bilimler Dergisi, Aralık 2021, Yıl: 3, Sayı: 7, 16-34.

Journal of Vocational and Social Sciences of Turkey, Dec 2021, Year: 3, No: 7, 16-34.

Görsel 7. At Yarışı Sponsorluğu ve İmaj Değeri

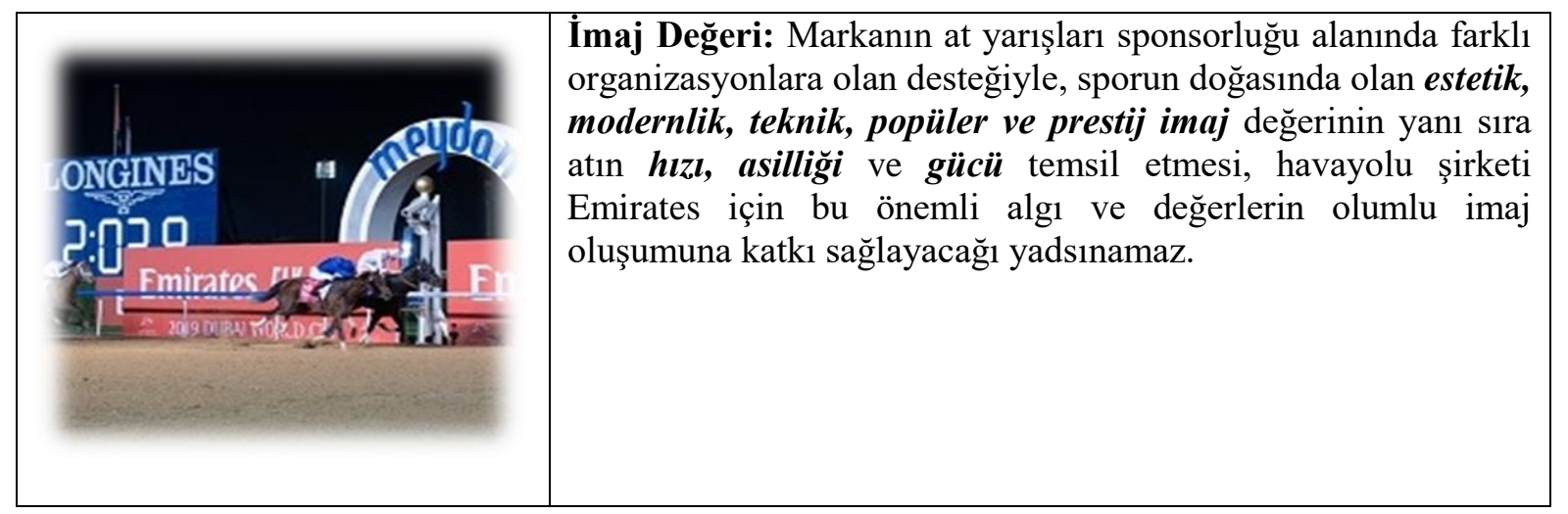

\subsection{Kriket}

Marka, kriket spor dalında, özellikle kriketin oynandığı ülkeler başta olmak üzere Asya, Avustralya ve Birleşik Krallık için düzenlenen en önemli uçuş ağları vasıtasıyla sinerji ortamı oluşturması, taraftar gruplarıyla birlikte toplumlarla da güçlü bir bağ kurulmasına yardımcı olması açısından sponsorluk faaliyetleri üstlenmektedir.

Görsel 8. Kriket Sponsorluğu ve İmaj Değeri

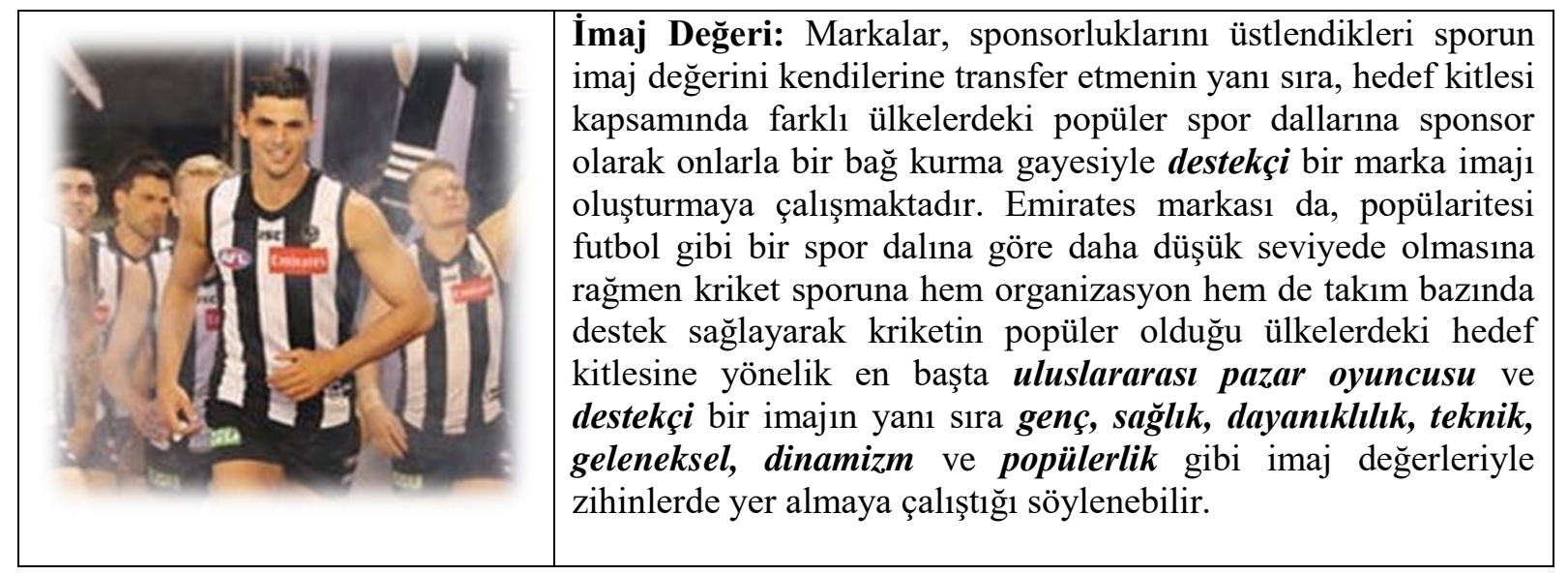

\subsection{Bisiklet}

Marka, bisiklet spor dalında, bisiklet takımlarının "disiplin, kararlılık ve tutkuyla" başarıyı elde etmeleri, markanın değerlerini yansıtması nedeniyle bu rekabetçi spora sponsorluk desteği vermektedir.

Görsel 9. Bisiklet Dalında Sponsorluk ve İmaj Değeri

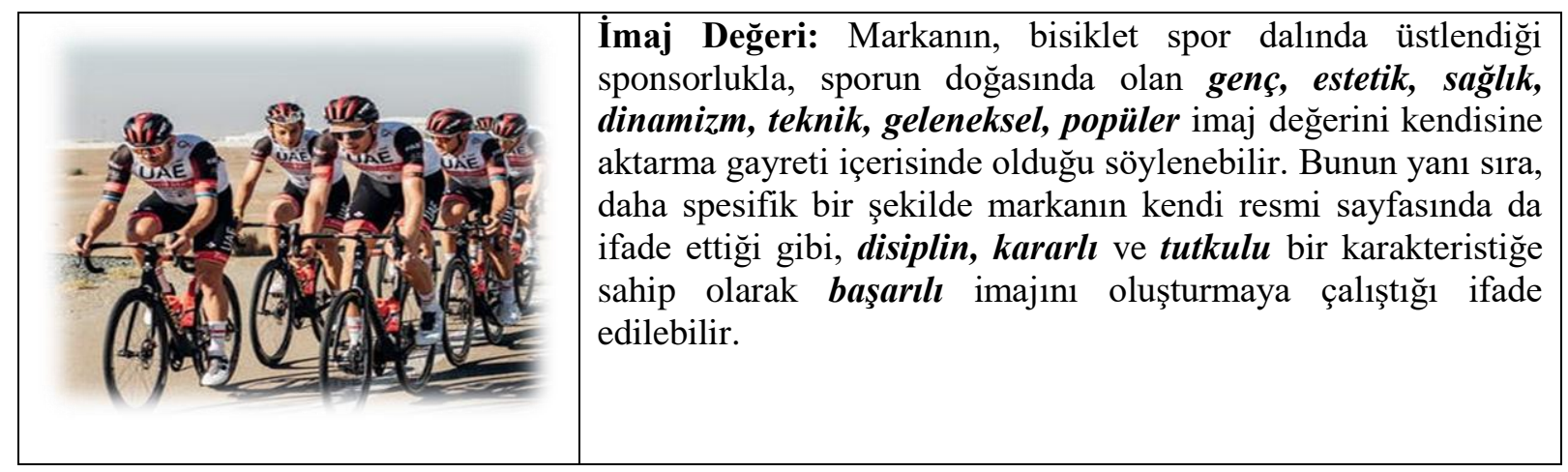


Türkiye Mesleki ve Sosyal Bilimler Dergisi, Aralık 2021, Yıl: 3, Sayı: 7, 16-34. Journal of Vocational and Social Sciences of Turkey, Dec 2021, Year: 3, No: 7, 16-34.

\subsection{Yelkencilik}

Marka, ilk olarak 2004 yılında "Emirates Team New Zealand" takımının isim sponsorluğunu üstlenmesinden bu yana, günümüz itibariyle "Amerika Kupası'nın” resmi havayolu iş ortağı olarak 2021 yılı ana organizasyona giden ön eleme yarışlarına da sponsor olmuştur. Bunun yanı sıra, Birleşik Krallık’ta gerçekleştirilen ACWS ile sunum iş ortaklığ gerçekleştirilmektedir.

Görsel 10. Yelkencilik Sponsorluğu ve İmaj Değeri

\begin{tabular}{|l|l|} 
& $\begin{array}{l}\text { İmaj Değeri: Marka, hem "Amerika Kupası Dünya Serisi } \\
\text { Portsmouth" gibi organizasyona hem de "Emirates Team New } \\
\text { Zealand" gibi takıma yönelik sponsorluk gerçekleştirerek } \\
\text { küresel bir oyuncu ve rekabetçi imajının yanı sira, daha } \\
\text { spesifik bir çerçevede yelkenli sporunun ana unsurları olan } \\
\text { deniz ve rüzgarın taşıdı̆̆ anlamlar bağlamında denizin uçsuz } \\
\text { bucaksı maviliğinde özgür ve tutkulu bir marka imaj1 } \\
\text { oluşturma gayreti içerisinde olduğu söylenebilir. }\end{array}$ \\
\hline
\end{tabular}

\section{SONUÇ}

Sponsorluk anlaşmasının tarafları, kaynakları ve becerileri paylaşmaktadır. Bu, marka imajı, pazarlama, planlama ve uygulama becerileri gibi maddi olmayan varlıkların, ne şekilde sponsorluk faaliyeti içerisinde yer alacağı ya da sunulacağı şeklinde de olabilmektedir (Farrelly ve Quester, 2005:226). Özellikle sponsorluk alanlarından olan spor sponsorluğunun, marka değerini ve tabii ki karı artırma çalışmaları, birkaç on yıldır pazarlamacıların ajandasında olan modern kurumsal pazarlamada önemli bir faktördür. Teknoloji giderek yaygınlaşmakta ve üreticilerin teknoloji ile rekabet avantajını sürdürme yetenekleri daha da zorlaşmaktadır. Benzer performans ve özelliklere sahip ürünleri ayırt etmek, yüksek fiyatlar, müşteri memnuniyeti ve sadakat için firsat oluşturma amacı pazarlama çabalarının artan bir meşguliyetidir. (Beck-Burridge ve Walton, 2001:167). Spor sponsorluğu, kurumsal hedeflere ulaşmada etkili bir pazarlama iletişimi aracı olabilir. Ancak spor sponsorluğunun bunu yapabilmesi için, öncelikle hedef kitle ve ilgilenilen ülke ile birlikte ulaşılacak hedefin belirlenmesi gibi çeşitli öncüllerin olması gerekmektedir. Hedef grup özellikle daha fazla araştırma dikkatine ihtiyaç duymaktadır. Çünkü tutkulu taraftarların, normal taraftarlara (yani sempatizanlara) kıyasla, sponsorlukla ilgili pazarlama faaliyetlerine olan algılarında ve tepkilerinde önemli ölçüde farklılıklar bulunmaktadır. Hedef kitleye yakın bir ilişki içinde ve hangi ülkede ulaşılacağını dikkate almak önemlidir. Ayrıca belirli piyasa durumuna bağlı olarak, farklı hedeflerin belirlenmesi gerektiğini göstermektedir. Bu nedenle, bir ülkede daha düşük bir farkındalık seviyesine sahip bir sponsor, sponsorun daha yüksek bir farkındalık seviyesi sergilediği başka bir ülkeden farklı bir hedef ve strateji seçmelidir. İki ülkede farkındalık düzeyleri aynı olsa bile, sponsorluk katılımının destekleyici işlevini teşvik etmeye dayanan bir iletişim stratejisi, sportif niteliklerin imaj transferinin nihai hedef ve strateji olduğu duruma kıyasla daha fazla sponsorluk etkinliği elde edebilmektedir. Sponsorluk hedefi ile ilgili olarak (örneğin farkındalık oluşturma), bir spor türü (örneğin futbol), bir ülke için (örneğin Almanya) doğru seçim olabilir ancak farklı bir spor türü (örneğin masa tenisi) başka bir ülkede daha iyi bir seçim olacaktır (örneğin Çin) (Lucas, 2015:146-147). Diğer taraftan sponsor olunacak organizasyon/etkinlik ya da sporcu/birey ile marka kişiliği ve hedeflenen amaçlara yönelik uyumluluk esası dikkate alınmalıdır. Ayrıca bir markanın, spor sponsorluğu faaliyeti içerisindeki diğer sponsorlara ilişkin hedef kitlenin taşıdığı olumsuz imaj ve değerler, kendisine de yansıyabileceği için bu durumun göz ardı edilmemesi önem arz etmektedir.

Sonuç olarak gerek küresel gerekse de ulusal çapta gerçekleştirilen spor sponsorluğu anlaşmalarının markanın imaj ve itibarını etkileyebilecek kaynaklar olarak düşünmek faydalı olsa da, spor sponsorluğunun gerçek ve potansiyel tüketiciler üzerinde nasıl bir etkisi olduğunu araştıran daha fazla 
Türkiye Mesleki ve Sosyal Bilimler Dergisi, Aralık 2021, Yıl: 3, Sayı: 7, 16-34. Journal of Vocational and Social Sciences of Turkey, Dec 2021, Year: 3, No: 7, 16-34.

çalışma yapılması gerekmektedir (Amis ve Cornwell, 2005:9). Bu bağlamda, markalar tarafindan gerçekleştirilen sponsorluk faaliyetlerine ve markalara ilişkin hedef kitlenin nasıl bir algıya sahip olduğunu ortaya koymak amacıyla anket tekniğinin kullanıldığı bir çalışma gerçekleştirilebilir.

\section{KAYNAKÇA}

Abd-el-Salam, E. M., Shawky, A. Y., \& El-Nahas, T. (2013). The Impact of Corporate Image and Reputation on Service Quality, Customer Satisfaction and Customer Loyalty: Testing the Mediating Role. Journal of Business and Retail Management Research, 8(1), 130-153.

Amis, J., \& Cornwell, T. B. (2005). Sport Sponsorship in a Global Age. J. Amis, \& T. B. Cornwell içinde, Global Sport Sponsorship (s. 1-18). Oxford: Berg Publishers.

Argan, M., \& Katırc1, H. (2002). Spor Pazarlaması. Ankara: Nobel Yayınları.

Bakan, Ö. (2005). Kurumsal Imaj . Konya: Tablet Yayınları.

Balta Peltekoğlu, F. (2014). Halkla İlişkiler Nedir? (8. Basım b.). İstanbul: Beta Basım Dağıtım.

Baş, M. (2008). Spor Sponsorluğu ve Spor Federasyonlarının Sponsorluğa Bakışı Üzerine Bir Araştırma. Gazi Üniversitesi İktisadi ve İdari Bilimler Fakültesi Dergisi, 10(3), 111-124.

Bayçu, S. (2012). Kurum Kimliği, Kültürü ve İmajı. F. Uztuğ içinde, Kurumsal İletişim (s. 46-70). Eskişehir: Anadolu Üniversitesi Yayınları.

Beck-Burridge, M., \& Walton, J. (2001). Sports Sponsorship and Brand Development. New York: Palgrave Macmillian.

Canöz, K., \& Doğan, İ. (2015). İmaj Oluşturma Aracı Olarak Sponsorluk. Gümüş̧hane Üniversitesi İletişim Fakültesi Dergisi, 3(2), 19-39.

Canöz, N. (2015). Hizmet Sektöründe Kurumsal Imaj Algısl. Konya: Palet Yayınları.

Collet, P., \& Fenton, W. (2011). The Sponsorship Handbook. San Francisco: Jossey-Bass Imprint.

Cornwell, T. B. (2020). Sponsorship in Marketing (2 b.). New York: Routledge.

Çetin, S., \& Tekiner, M. A. (2015). Kurumsal İmajın Temel Belirleyicileri: Emniyet Teşkilatı Örneklemi İç Paydaş Anketi. Yönetim ve Ekonomi Araştırmaları Dergisi, 13(1), 418-440.

Çoşkun, H. (1999). Bir Tutundurma Aracı Olarak Spor Sponsorluğu. Gazi Beden Eğitimi ve Spor Bilimleri Dergisi, , 4(3), 63-68.

Farrelly, F., \& Quester, P. (2005). Examining International Alliances through Sponsorship. J. Amis, \& T. B. Cornwell içinde, Global Sport Sponsorship (s. 225-242). Oxford: Berg Publishers.

Ferrand, A., Torrigiani, L., \& Povill, A. C. (2007). Routledge Handbook of Sports Sponsorship. New York: Routledge.

Gray, E. R., \& Balmer, J. M. (1998). Managing Corporate Image and Corporate Reputation. Long Range Planning, 31(5), 695-702. doi:DOI: 10.1016/S0024-6301(98)00074-0

Grohs, R., \& Reisinger, H. (2014). Sponsorship Effects on Brand Image: The Role of Exposure and Activity Involvement. Journal of Business Research(67), 1018-1025.

Gross, P. (2015). Growing Brands Through Sponsorship. Wiesbaden: Springer Gabler .

Güzelcik, E. (1999). Küreselleşme ve İşletmelerde Değişen Kurum İmajı. İstanbul: Sistem Yayınları.

Gwinner, K. (2005). Image Transfer in Global Sport Sponsorship:Theoretical Support and Boundary Conditions. J. Amis, \& T. B. Cornwell içinde, Global Sport Sponsorship (s. 163-178). Oxford: Berg Publishers.

Koçak, S., Varol, M. Ç., \& Varol, E. (2020). Dijital Ortamda Marka İmaj Transferi ve İtibar Göstergeleri: RolexRoger Federer Örneği. Uluslararası Kültürel ve Sosyal Araştırmalar Dergisi, 6(2), 597-625. doi: 10.46442 /intjcss. 803493

Lucas, C. (2015). Sponsor and Country Related Predictors of Sponsorship Effectiveness. Wiesbaden: Springer Gabler.

Masterman, G. (2007). Sponsorship . Oxford: Elsevier.

Meenaghan, T. (2005). Evaluating Sponsorship Effects. J. Amis, \& T. B. Cornwell içinde, Global Sport Sponsorship (s. 243-264). Oxford: Berg Publishers.

Melovic, B., Rogic, S., Smolovic, J. C., Dudic, B., \& Gregus, M. (2019). The Impact of Sport Sponsorship Perceptions and Attitudes on Purchasing Decision of Fans as Consumers-Relevance for Promotion of Corporate Social Responsibility and Sustainable Practices. Sustainability, 11(6389), 1-16. doi:doi:10.3390/su11226389

Okay, A. (2012). Sponsorluk. İstanbul: Der Yayınları.

Okay, A. (2013). Kurum Kimliği. İstanbul: Derin Yayınları.

Oliver, M. S. (2004). Handbook Of Corporate Communication And Public Relations, . London: Routledge. 


\section{TÜRKIYE MESLEKI VE SOSYAL BILIMLER DERGISI}

Türkiye Mesleki ve Sosyal Bilimler Dergisi, Aralık 2021, Yıl: 3, Sayı: 7, 16-34.

Journal of Vocational and Social Sciences of Turkey, Dec 2021, Year: 3, No: 7, 16-34.

Özer, M. A. (2009). Halkla İlişkiler Dersleri. Ankara: Adalet Yayınları.

Özer, M. A. (2013). İmajını Yöneten Örgütler Daha mı Başarılı Oluyor? TÜHİS İş Hukuku ve İktisat Dergisi, $24(3), 26-45$.

Öztürk, S. A. (2013). Spor Sponsorluğu: Kavram ve Özellikler. M. Argan içinde, Sporda Sponsorluk (s. 2-26). Eskişehir: Açık Öğretim Fakültesi Yayınları.

Özüpek, M. N. (2005). Kurum Imajı ve Sosyal Sorumluluk. Konya: Tablet Yayınları.

Polinkevych, O., \& Kamiński, R. (2018). Corporate İmage in Behavioral Marketing of Business Entities. Innovative Marketing, 14(1), 33-40. doi:10.21511/im.14(1).2018.04

Pope, N. K., \& Voges, K. E. (2000). The Impact of Sport Sponsorship Activities, Corporate Image, and Prior Use on Consumer Purchase Intention. Sport Marketing Quarterly, 9(2), 96-102.

Pope, S. (1998). The Manager's Pocket Guide to Team Sponsorship . Massachusetts: HRD Press.

Roy, D. (2005). Global Sport Sponsorship: Towards a Strategic Understanding. J. Amis, \& T. B. Cornwell içinde, Global Sport Sponsorship (s. 147-162). Oxford: Berg Publishers.

Soyer, F. (2003). Sporda Sponsorluk Kavram, Kapsam ve Bir Araştırma. Ankara: Gazi Kitabevi.

Tekin, N., \& Eroğlu Eskicioğlu, Y. (2015). Spor Sponsorluğu: Türk Hava Yollar1-Türkiye Basketbol Federasyonu Örneği,. Spor Yönetimi ve Bilgi Teknolojileri Dergisi, 10(1), 14-36.

Temel, A. S., \& Sirın, E. F. (2017). The Relationship Between Sports Sponsorship And Corporate Image, Reputation And Intention to Buy: TORKU Case. Turkish Journal of Sport and Exercise, 19(2), 241-253.

Tengilimlioğlu, D., \& Öztürk, Y. (2004). İşletmelerde Halkla İlişkiler. Ankara: Seçkin Yayıncılık.

Upamannyu, N. K., Bhakar, S., \& Gupta, M. (2015). Effect of Corporate Image on Brand Trust and Brand Affect. International Journal of Applied Science-Research and Review, 2(1), 20-33.

Yaman, F., \& Açıkgözoğlu, S. (2016). Bir Tutundurma Aracı Olarak Sponsorluk: Spor Sponsorluğunun Hatırlanabilirliği ve Satın Alma Davranışı Üzerine Etkisi. Global Business Research Congress (GBRC), (s. 535-543). İstanbul.

Yelken, H., \& Ak, B. (2018). Beden Eğitimi ve Spor Yüksekokulu Öğrencilerinin Spor Sponsorluğu Hakkındaki Görüşlerinin İncelenmesi. Adlyaman Üniversitesi Sosyal Bilimler Enstitüsü Dergisi, 10(29), 281-307.

Yılmaz, R. A. (2007). Marka Farkındalığı Oluşturmada Sponsorluk ve Rolü: Eskişehir Sinema Günleri’ne Yönelik Bir Değerlendirme. Sosyal Bilimler Dergisi(1), 587-607. 
Türkiye Mesleki ve Sosyal Bilimler Dergisi, Aralık 2021, Yıl: 3, Sayı: 7, 16-34.

Journal of Vocational and Social Sciences of Turkey, Dec 2021, Year: 3, No: 7, 16-34.

\section{THE ROLE OF SPORTS SPONSORSHIP IN BUILDING CORPORATE IMAGE}

\section{EXTENDED ABSTRACT}

In today's competitive environment, corporate image and reputation play the most important role in achieving brands' goals. One of the commonly used methods of creating a positive corporate image is sponsorship activities. The fact that the sports sector develops every year and is a phenomenon that involves the masses by direct or indirect means also increases the attractiveness of the sport. Sponsorship is a relational marketing tool that creates mutual brand and business value for both sponsored and sponsored events. Sports sponsorship, which covers sports activities, especially due to its constant media coverage and attracting large audiences, presents important opportunities for brands that aim to promote their products to large audiences, as it appeals to large audiences. For this reason, it is preferred by brands that want to introduce their products and services to large audiences in a short time. In this context, sports sponsorship is a very successful communication channel to create a loyal consumer base by providing a positive image. The study aims to demonstrate how institutions/brands use sports sponsorship to create a positive corporate image for both their internal and external target audience. In this context, how institutions/brands will benefit from sports sponsorship, how sports branches will use their image values within the framework of corporate goals and issues that are important when carrying out sports sponsorship were interpreted through an international airline brand by literature review. From this point of view, the study aims to contribute to the theoretical development of the field by addressing the role of sport sponsorship which is one of the practices of public relations, in creating a corporate image.

Each sponsorship event or branch has a specific image value that can be transferred to internal or external audiences. Image transfer is positively influenced by a large number of common perceptions of sponsor and event, audience attitudes towards sponsor and event connotations (Y1lmaz, 2007:592). Sponsorship activities carried out by brands have some image values. For example, an organization can sponsor sports for the purpose of creating a healthy, young, energetic, fast, vibrant and masculine image value or one of its values. In addition, some sponsorship areas have the following image values. High-face art sponsorship is sophistic, elite, discriminatory, upper market, serious and showy; Mass arts is young, accessible, friendly, popular, innovative and commercial; Social sponsorship is admirable, thoughtful, interested, smart and abusive; Environmental sponsorship is relevant, thoughtful and abusive (Okay A., 2012:82). Each sponsorship area has a certain image value. But brands/institutions have the opportunity to transfer more specific perceptions to their brands and institutions with the image values that they carry unique to many sports branches that they sponsor through sports sponsorship that they will undertake. Although each sports branch has some common image values, it is also seen that they differ. For this reason, the presence of a large number of sports branches that brands and organizations can use for the positive and specific image they want to create in line with their corporate goals puts sports sponsorship in a more attractive position than others.

The stakeholders to the sponsorship agreement share resources and skills. This can also be in the form of how intangible assets such as brand image, marketing, planning and implementation skills will be involved or presented in sponsorship activities (Farrelly and Quester, 2005:226). Especially Sports sponsorship from the fields of sponsorship is an important factor in modern corporate marketing which has been on the marketers' agenda for several decades, trying to increase brand value and course, profit. As technology becomes more widespread, manufacturers' ability to maintain a competitive advantage becomes more difficult. The goal of distinguishing products with similar performance and characteristics, creating opportunities for high prices, customer satisfaction and loyalty, is a growing preoccupation of marketing efforts (Beck-Burridge and Walton, 2001:167). Sports sponsorship can be an effective marketing communication tool in achieving corporate goals. But in order for sports sponsorship to do this, there must first be various antecedents, such as determining the goal that will be achieved together with the target audience and the country of interest. The target group in particular needs more research attention. Because there are significant differences in the perceptions and reactions of passionate fans to sponsorship-related marketing activities compared to regular fans (i.e. sympathizers). It is important to consider to the target audience in a close relationship and in which country it will be reached. It also shows that different targets should be set, depending on the specific market situation. Therefore, a sponsor with a lower level of awareness in one country must choose a different goal and strategy from another country, where the sponsor exhibits a higher level of awareness. Even if the levels of awareness are the same in the two countries, a communication strategy based on promoting the supportive function of sponsorship participation can achieve more sponsorship activities compared to the situation where image transfer of sporting qualities is the ultimate goal and strategy. Sponsorship related to the target (e.g., awareness), a sport (e.g. football), a country (e.g. Germany) might be the right choice but a different type of sport (e.g. table tennis) would be a better choice in another country (e.g. China) (Lucas, 2015:146-147). In addition, the issue of 


\section{TÜRKIYE MESLEKI VE SOSYAL BILIMLER DERGISI}

Türkiye Mesleki ve Sosyal Bilimler Dergisi, Aralık 2021, Yıl: 3, Sayı: 7, 16-34.

Journal of Vocational and Social Sciences of Turkey, Dec 2021, Year: 3, No: 7, 16-34.

compatibility between the organization/event to be sponsored or the athlete/individual and the brand personality and the intended goals should be taken into account. Furthermore, it is important not to ignore this situation, as the negative image and values of a brand that the target audience carries regarding other sponsors within the sports sponsorship activity may also be reflected its.

As a result, while it is useful to consider sports sponsorship agreements, both globally and nationally, as sources that can affect the brand's image and reputation, more work is needed to investigate how sports sponsorship has an impact on real and potential consumers (Amis and Cornwell, 2005:9). In this context, a study using the survey technique can be carried out in order to show how the target audience has a perception of the sponsorship activities carried out by the brands and the brands. 